\title{
Understanding social accountability: politics, power and building new social contracts
}

\begin{abstract}
Calls to deepen levels of social accountability within social protection interventions need to be informed by the now extensive experience of promoting social accountability in developing countries. Drawing on a systematic review of over 90 social accountability interventions, including some involving social protection, this paper shows that politics and context are critical to shaping their success. We argue that the politics of social protection and of social accountability resonate strongly with the broader project of transforming statesociety relations in developing countries. This requires a reconceptualisation of social accountability and social protection in terms of the broader development of 'social contracts', and that the current emphasis on promoting bottom-up forms of accountability needs to be balanced by efforts to strengthen and legitimise public authority in developing countries.
\end{abstract}

\section{INTRODUCTION}

Devereux et al. (2011) argue that for social protection to be transformative it must go beyond the management of risk towards tackling the underlying causes of vulnerability. These causes encompass forms of exclusion and disadvantage that are political as well as socio-economic in form. There is therefore growing pressure for social protection interventions to be delivered in ways that enable recipients to exercise agency in holding providers to account for delivering social protection as a right rather than as a handout. This move fits with wider calls for both social accountability and social protection to be reconceptualised in terms of a wider project of forging a more just social contract (Joshi and Houtzager 2012; Hickey 2011). To help move this agenda forward, our paper summarises findings from an extensive review of 
research into social accountability initiatives (SAIs) in order to firstly, inform the process of incorporating SAIs within social protection interventions, and secondly, examine the broader implications in terms of establishing more progressive and just forms of state-society relations. It begins with an overview of current debates around social accountability and a discussion of the methodology underpinning the review. The third section presents findings about the kinds of intervention and contextual factors that shape the outcomes achieved by SAIs. This is followed by an analysis of the political considerations critical to understanding and engaging with social accountability in different environments which proposes an analytical framework to help organize thinking and action in this field. The final section discusses the implications of promoting social accountability within social protection interventions as a means to promote more progressive social contracts.

\section{UNDERSTANDING SOCIAL ACCOUNTABILITY}

Social accountability has come to occupy a central position within inclusive liberal discourse focused on the achievement of 'poverty reduction through good governance', a policy agenda that has also come to include a central role for social protection (World Bank, 2001, 2014). Achieving higher levels of accountability, whereby governments not only deliver goods and services as per their policy promises, but are also responsive to citizens' demands, is considered to contribute to better public service provision while also building a stronger sense of citizenship and promoting empowerment. Social accountability is a contested concept but is most usefully defined here as 'the broad range of actions and mechanisms beyond voting that citizens can use to hold the state to account, as well as actions on the part of government, civil society, media and other societal actors that promote or facilitate these efforts' (Malena and McNeil, 2010: 1). There is a consensus that accountability involves both answerability, 'making power holders explain and give reasons for their actions', and 
enforcement, 'ensuring that poor or immoral performance is punished in some way' (Hickey and Mohan, 2008: 236). Initiatives designed to ensure answerability and enforcement may be demand-side - driven from the bottom-up by non-state actors, or 'supply-side' encompassing legal and fiscal governmental checks and balances; and, as we come to argue, may most effectively comprise elements of both.

Under the Post-Washington Consensus, demand-side approaches took centre stage, but more recently these 'social' forms of accountability have come under criticism for being based on a theory of change that does not reflect the political realities of governance and development in most developing countries (Booth, 2012; Brett, 2003). It has also been argued that most SAIs are conceptualised in instrumental and technical, rather than political terms (Joshi and Houtzager, 2012), thereby 'over-emphasizing the tools to the detriment of analysis of context,' (McGee and Gaventa, 2011: 8), despite evidence that their success is highly dependent on the political, social and economic landscape in which SAIs are embedded (Menocal and Sharma, 2008; McGee and Gaventa, 2011). It is therefore particularly important that both thinking and practice around social accountability is strongly informed by the available evidence concerning what works well in particular places, rather than by predetermined preferences for particular institutional forms and approaches.

This paper draws on a systematic review of the social accountability literature that investigated the key contextual factors shaping the outcomes of SAIs. The review was formulated in part as a challenge to the 'best-practice' approach to designing development interventions, supportive instead of a 'best-fit' approach that is more closely aligned with the realities of different political economy contexts (see Booth, 2012). The review, which followed recommended academic practice (Gough et al., 2013), included 91 research studies, 
of which 44 were empirical investigations, 18 were synthesis papers, and 29 were generic studies (which covered topics such as decentralisation with clear relevance to the question of how context affects social accountability). Initiatives were judged as either successful, partially successful or as failed according to the evidence and conclusions presented within each study. 'Success' here was considered not merely in terms of the successful delivery of projects and improvement in services generated by the interventions, but also at the broader level of outcomes and impact, with a particular focus on changes in governance institutions and/or citizen empowerment vis-à-vis the state.

The review covered three main types of SAI, namely transparency initiatives that seek to increase citizen access to information about state services (e.g. Public Expenditure Tracking Surveys, citizen score cards, and social audits); contentious actions, such as popular demonstration, advocacy and campaigns, and public interest litigation, and also what Hossain (2010) refers to as 'rude' or informal accountability actions including undressing, shouting and spreading rumours; and participatory governance initiatives which principally incorporated consultations within poverty reduction strategy papers, participatory budgeting and membership of community management committees.

Selection of research studies followed a thorough bibliographic search of literature pertaining to social accountability, and included research drawing on a range of methodologies such as experimental designs, survey-based studies, and specialized synthesis reviews. In the interests of generating robust and up-to-date findings, only studies with clear methodological rationales published between 2000 and 2012 were included. A qualitative categorical analysis of outcomes, and intervention and context-based factors shaping these outcomes, was conducted with the assistance of Nvivo 9 software, which enabled us to identify specific 
factors which were associated with success in particular cases, and undertake coding and categorization accordingly.

This approach encountered two main methodological challenges. First, there are few studies of SAIs in different political-economic environments which focus specifically on the role of context in shaping outcomes. Most evaluative literature has been commissioned by development agencies which tend to emphasize the role of technical tools and institutional mechanisms rather than the role of context. The second challenge concerned the validity of generalizing from our approach. Although the methodology outlined here was judged to be fairly rigorous, particularly in terms of the number of studies covered and the mode of analysis employed, it remains problematic within a qualitative methodological approach to seek to abstract categories from different types of study conducted in different types of context, when it is difficult to be confident that any one factor is being defined or understood in the same ways across studies. This would involve undertaking systematic and primary comparative case-study analysis of SAIs in different types of context, something which we argue later should provide the basis for future work in this area.

\section{WHAT SHAPES THE SUCCESS OF SOCIAL ACCOUNTABILY INITIATIVES?}

This section focuses mainly on the role of contextual factors in shaping SAI outcomes before turning briefly to the role played by intervention-based factors.

\section{Context-based factors}

A wide range of contextual factors emerged as significant within the literature on SAIs, including the role of different kinds of political institutions, the type and capacity of civil 
society actors involved in promoting social accountability, and a wide range of different 'relational' factors, whether in the form of state-society relations or relations between groups and citizens. Forty-five out of the total ninety-one studies reviewed identified the presence or absence of political will at different levels of governance as a critical factor. ${ }^{1}$ For example, one NGO in Madhya Pradesh, Samaj Pragati Sahyog (SPS), which managed to promote higher levels of social accountability, greatly benefited from the support of a senior district official with the authority to impose sanctions upon corrupt junior officials (Chhotray, 2008). Likewise, several studies showed SAIs were undermined by a lack of strong and visible official support, as around the community management committees in the health sector in Bangladesh (Mahmud, 2007), or housing associations in Kenya (Nyamu-Musembi, 2006: 137). Corbridge et al. (2005) reveal how bureaucrats and politicians with vested interests in maintaining the status quo actively sabotaged new SAIs. Political will is thus to some extent shaped by the degree to which SAIs offer viable solutions to governance problems that are in alignment with the interests of the political power holders involved.

Well-institutionalized political parties and political opposition can also play key roles within accountability dynamics. Political support from opposition parties can contribute to SAI success as evidenced by better performing community management committees in Midnapore, India, where the communist party was influential in mobilizing the poor (Corbridge et al., 2005), and by differential levels of support for participatory budgeting in Latin America closely linked to political party membership (Goldfrank, 2007).

The effects of democratisation on efforts to secure accountability emerge as somewhat ambiguous. Certainly in contexts like Brazil and South Africa, the existence of particular constitutional rights and competent judiciaries have been critical to triggering movements for 
legislative accountability like those led by the landless workers movement $(M S T)$ and the Treatment Action Campaign (TAC) (Campbell et al., 2010). NGOs such as SPS in India also rely on legislative guidelines to fuel citizen mobilisation (Chhotray, 2008), and transparency initiatives have even experienced at least partial success in semi-authoritarian contexts like Uganda (Robinson, 2006). Participatory initiatives are often ineffective, however, in areas where local governments lack resources and bureaucratic competence. Poor facilitation of citizen participation in local governance in eastern India, for example, has been linked to weak incentives for good performance and limited opportunities for career progression (Corbridge et al., 2005).

The capacity of CSOs, and in particular the depth, extensiveness and character of the relationships amongst CSOs, and between civil and political society, plays a critical role in determining the success of SAIs. The availability of credible and capable civil society allies and a history of effective grassroots mobilisation emerged as particularly strong components within the successful contentious actions reviewed. TAC in South Africa, for example, gained strength from activist experiences of the historic struggle against apartheid and from the strategic bridging relationships available with academics, churches, international activist organizations and trade unions with significant political influence (Campbell et al., 2010). The inverse of this is that high levels of competitiveness between CSOs, often linked to a highly donor dependent operating environment, can contribute to failure, as this tends to fragment collective action. Environments with high levels of clientelism may also be poor incubators of coalitional action (Goldfrank, 2007), given that the vertical character of patronclient relations tends to undermine the emergence of horizontal forms of collective action (Mitlin, 2013). 
High levels of inequality between citizens can limit the success of SAIs. Low levels of income and education have a direct effect on citizen capabilities for participation particularly in formal participatory spaces. Campbell et al. (2010) suggest that initiatives can attempt to mitigate these effects by incorporating the provision of citizen education and capacity-building into interventions. Studies of demand-side mobilisation in Bangladesh (Kabeer et al., 2010), and also, more recently, in Uganda (King, 2015), suggest that securing the participation of poorer citizens in initiatives for social justice may do better when linked directly to potential livelihood and economic gains. Finally, socially subordinate groups sometimes rely on informal methods for extracting accountability, and the review suggested that these strategies are often pursued in contexts where governance is weak and civil society lacks the capacity or inclination to hold civil servants to account (Hossain, 2010).

The character of state-citizen relations is also important as this relational field directly shapes capacity for, and commitment to, activism for social justice among citizens and civil society actors. Inequality and exclusion can be the impetus for collective action - in the case of the MST landless movement in Brazil for example. It can also undermine drives for participation and inclusion. Studies show that village education committees in eastern India are dominated by local teachers, upper-caste landlords and their kinsmen, and that the social exclusion endured by lower castes contributes to their much lower levels of political awareness and involvement (Corbridge et al., 2005). Where political and economic power are intertwined, local citizens may fear to express their views openly, for example, villagers participating in social audits in India have feared reprisals from local officials (Shankar, 2010). 


\section{Intervention-based factors}

Thirty-five out of the ninety-one studies reviewed found the credibility of lead actors to be critical to success and this was particularly significant within transparency initiatives and contentious actions. Transparency advocates needed to show capability in extracting, managing and disseminating reliable data. Key credibility considerations for participatory governance initiatives in twelve out of the nineteen studies reviewed were that institutions and processes 'had teeth' in terms of being able to impose sanctions for poor performance or corruption. Thirty-six studies found that higher levels of state-civil society collaboration within accountability mechanisms translated into greater success. Where CSOs were left out of initiatives like poverty reduction strategy paper processes or transparency initiatives, the kinds of accountability achieved were weak. Even within contentious actions, which might be expected to involve adversarial state/activist relationships, receptivity to civil society advocacy among political actors, and effective interfaces for engagement, were important to success. The persistence of mobilization over time also contributed to effective influence, suggesting it may be important to consider social accountability as the outcome of longerterm and iterative processes of bargaining between social and state actors (Joshi and Houtzager, 2012), rather than one-off interventions.

Improving the access of citizens to high quality, relevant information was critical to both transparency and participatory governance initiatives. Key considerations were whether information was supportive of attention-grabbing public messages; the degree to which information offered citizens clear and practical data that they could make sense of and use; and in relation to participatory governance mechanisms, whether opportunities were widely and appropriately publicized. Another important success factor in thirteen studies was the degree to which an issue resonated strongly with citizens - education, livelihoods, access to 
land and access to life-saving medicines have all catalyzed strong reactions from citizens across the three regions covered by the review. Finally, synthesis studies and research into transparency initiatives and contentious actions in particular, stressed the importance of taking an integrated approach to promoting social accountability that combined both demandand supply-side factors; or from the demand-side, employing multiple interlinking strategies such as litigation, community mobilization, and media campaigns.

\section{Summary}

That context and politics matter to development outcomes is nothing new. This review demonstrates specifically however, that the pursuit of downwards accountability is advanced by the presence of state actors interested in building alliances with civil society, of coalitionminded civil organizations and citizens that display interest in participating in governance mechanisms, and of design features that reduce the asymmetric distribution of status and resources among participants. Bottom-up accountability interventions generally achieve greater success where they are able to forge synergies with top-down and/or horizontal accountability mechanisms. Success is particularly closely linked to levels of political will amongst state functionaries, especially those in elected positions able to hold service providers to account. The choice of public goods around which accountability is sought is also important, suggesting that a stronger 'social contract' exists around some public goods than others, based on the historically-informed expectations of actors on both sides of the governance equation.

\section{ANALYSING SOCIAL ACCOUNTABILITY IN CONTEXT}


There is a strong convergence between the findings reported above and the growing focus on the politics of development over the past ten years, particularly work that focuses on the forms of politics and power which underlie and shape the performance of institutions (such as Leftwich, 2005; North et al., 2009) and on the importance of state-society relations (Unsworth and Moore, 2010). Importantly, this convergence challenges many of the underlying assumptions that have tended to characterise most mainstream thinking and practice on social accountability (and 'good governance' more broadly) over the past decade (World Bank, 2004), within which "the common feature is assumed to be the mobilisation of citizen demand for accountability" (Booth 2012: 69), and suggests the need for reconceptualising this work within a more contextually and politically attuned theory of change. This section therefore takes a political lens to organising the findings of the review into an analytical framework that can inform attempts to understand accountability dynamics. The first part of the discussion identifies four dimensions for this framework and briefly relates these to other generic studies of SAIs; the second part unpacks each of these dimensions, and their interrelationships, in greater depth.

\section{The contextual dimensions shaping social accountability}

Although the particular configuration of contextual factors that matter most in shaping SAIs differs from place to place, and also over time, the evidence examined for the above review suggests that the most critical features can be categorized into four overarching dimensions. These comprise the two institutional spheres of civil and political society and their interactions, as located within the broader fields of power relations between states and societies and within society. Figure 1 offers a provisional suggestion as to how these dimensions might be mapped in relation to each other and also identifies the key factors within each of them, with a particular focus on capacities, commitment and the inter- 
relationships between key actors and spheres. In a holistic sense, the diagram represents the politics of social accountability in terms of the broader social contract between states and citizens around the protection of rights and the provision of resources.

At first glance, our key findings on how context matters for accountability outcomes are broadly in accord with those reported in a number of other recent synthesis studies. O'Neill et al. (2007) identify political contexts, existing power relations, the enabling environment, the nature of the state and its institutions, and the social contract between state and citizens as key variables shaping SAI outcomes. Both Menocal and Sharma (2008) and Agarwal and Van Wicklin (2011) note the significance of capacity and commitment on both sides of the state-society equation. Several of the studies reviewed by McGee and Gaventa (2011) also note the significance of supply-led factors in ensuring SAI success, particularly in terms of legitimate state authorities imposing sanctions on public officials. In most cases, civil society activism without reforms on the other side of the equation will fail to yield sustained results. However, and by their own admission (as noted by McGee and Gaventa, 2011), these studies lacked the systematic basis of this one, and few have gone on to show either how these different factors can be conceptualised in relation to each other, or through breaking these down into more specific forms (Figure 1).

Figure 1: Contextual factors that influence social accountability

INSERT FIGURE ONE HERE

\section{Political Society}

Political society is critical to SAI success, particularly regarding the political will of state functionaries and the role played by political institutions (such as political parties) that appear 
from the evidence of our studies to mediate the effects of democratisation. Political society is viewed here, following Corbridge et al.'s (2005: 189) discussion of Partha Chatterjee's 2004 work, as the arena within which people perceive and encounter the state on an everyday basis and which creates and maintains different patterns of political rule that shape the scope for 'citizenship empowerment'. It is constituted by a loose community of recognised political parties, local political brokers and councillors, public servants, a set of institutions, actors and cultural norms that provide the key links between 'government' and 'the public'. For Chatterjee, it is the identity and quality of the actors who mediate power in political society that matter most in shaping the lived experience of citizenship, even if civil society actors can help mediate these encounters in favour of greater accountability towards citizens. We focus here on the three elements of political society that emerge as most important for the effective operation of social accountability, namely commitment, capacity and the nature of key political institutions.

The commitment of key actors to promoting social accountability, both in terms of bureaucrats and elected officials has emerged as central here and in other meta-reviews (McGee and Gaventa, 2011). Houtzager and Joshi (2008: 6) emphasise the critical role played by public sector officials in not only delivering on accountability demands, but also pushing for accountability reforms, and even stimulating social actors to mobilise for claimsmaking. Our studies tend to emphasise the role played by elected representatives who are both susceptible to popular pressures and also in a position to shape the behaviour of public officials through sanctions and other forms of supply-led accountability. This points to the need to think about ways of linking social accountability interventions with forms of political accountability, particularly through making links to supply-led enforcement mechanisms and involving elected officials in the design of demand-side initiatives. 
There have been a number of calls to unpack the notion of political will, but few analyses have managed to go beyond a standard disaggregation of political actors into different types such as elected representatives or public sector professionals as we have done here. Others have argued that it is more useful to move beyond the language of political will or commitment to examine the 'incentives' that structure and guide elite behavior (Booth, 2012). This focus on elite interests and incentives links to a new wave of thinking around what shapes not only the commitment of elites to development but also the capacity of states to deliver, which focuses on the character of the 'political settlement' (North et al., 2009; Khan, 2010). The 'political settlement refers to the balance or distribution of power between contending social groups and social classes, on which any state is based' (di John and Putzel, 2009: 4). The key implication here is that the commitment of elites to development, and the capacity of the state to deliver, will be strongly shaped by the terms of the political settlement and the incentives that this places before them to act in favour of certain interests over others. Ruling coalitions need to maintain certain types of relationship both horizontally (with other elite factions) and vertically (with organized social groupings) in order to preserve regime stability and survival, and this creates strong incentives to act in particular ways.

This approach also offers a more nuanced and relational reading of the capacity of public and elected officials to act in the public interest, around accountability issues but also more broadly. The developmental capacities of the state need to be defined not only in terms of its organizational competence (levels of human resource and bureaucratic capacity for example), but also its capacity to forge and maintain synergistic relations with different social actors (vom Hau, 2012). Whereas the key relationships that matter for economic growth are those between state and capital (Evans, 1995), the successful promotion of human capabilities is 
more strongly associated with states characterized by co-operative and synergistic relations between political and civil society (Evans, 2010). This analytical approach might be further advanced by extending the focus on 'incentives' away from an instrumental reading to one that also takes account of the role that 'ideas' (around notions of public service for example) play in shaping elite behavior (Hickey, 2013).

A focus on the specific forms of politics and power relations shaping SAIs may be more useful than grappling with broad concepts like democratisation. What seems to matter here are the forms of state-society relations within which accountability resides, and also, the types of political institutions that mediate the relationship between democratic procedures, like elections and public policy processes. For example, Brautigam's (2004) review of participatory budgeting notes that democracy or even popular participation per se is less significant in achieving government responsiveness to pro-poor concerns than the role of well institutionalized and programmatic political parties. This suggests a need to introduce a clearer focus within current thinking on social accountability concerning the ways in which participatory and representative forms of democracy can be woven together to achieve greater success. The preceding discussion suggests that a particular focus on the social and ideological character of particular political organizations, and greater collaboration between social accountability advocates or activists and elected officials and political parties, might further improve identification and design of interventions.

Overall, the evidence suggests that the capacity and commitment of actors within political society to undertake effective forms of governance reform are closely shaped by the incentives with which they are presented, and the room for manoeuvre available to them 
within the broader field of power relations. This focus on power relations is central to our analysis here, and is explored further below.

\section{Civil Society}

The success of SAIs relies heavily on the capacity of civil society organisations (CSOs) to mobilise citizens and to network effectively, both within civil and political society. CSOs are unable to achieve much by acting alone, and their capacity to develop alliances with those pursuing similar projects is critical to accumulating the power required to achieve change. The type of civil society that emerges as significant from this review is a much more politicised and relational realm than the de Tocquevillian vision of an associational realm that operates in a distinct sphere from the state (Hyden, 1997), and which has generally been promoted within international development theory and practice over the past two decades. Here, 'civil society' is not free from the logic of how power and politics operate in developing countries, but a space within which citizens and CSOs often find it very hard to find room for manoeuvre for their projects within the broader politics of patronage, ethnicity and exclusion. Agency within civil society is closely shaped by the underlying field of power relations, involving forms of inequality and exclusion along economic, social and cultural lines. Importantly, the capacity of CSOs to be effective in this realm has less to do with their autonomy from the state than with the relationships and networks that they are able to forge with other actors in both civil and political society over time (also Lavalle et al., 2005). This version of civil society is best captured within a Gramscian reading of civil society, which recognises the power relations that shape civil society and the historical fact that progressive struggles are nearly always constituted by actors from both sides of the state-society divide (Bebbington et al., 2008; Fox, 2004), an issue we return to below. This should direct advocates of social accountability away from assessing the 'strength' of civil society alone, 
and towards identifying and assessing the nature of the relationships and networks across state and society and supporting their strengthening in more progressive directions.

The available literature is less useful in breaking down which elements of civil society are particularly important in shaping social accountability and the drivers behind such agents. However, what appears to matter most is the capacity and commitment of citizens and CSOs to mobilise and act, both individually and collectively, around social accountability demands, particularly those involving contentious actions and direct participation. In terms of CSO capacity, 'mobilization, coalition-building, negotiation, and advocacy' (Agarwal and Van Wicklin, 2011: 7) are critical. The origins of these capacities are not made clear in the particular studies, although at the collective level, it seems likely that these are built up over time through successive rounds of bargaining with the state (Houtzager and Joshi, 2008), often over a prolonged period. An example is the $M K S S^{\prime}$ right to information campaign in India, which started in the early 1990s, gained partial success in 2000 when the Indian state of Rajasthan passed the right to information act (Ramkuma, 2008), but continued for another five years before the nation-wide Right to Information Act (RTI) was passed (Aiyar, 2010; Ramkuma, 2008).

\section{Inequality and Exclusion}

The field of power relations that shapes social interactions and popular agency within society plays a cross-cutting role in shaping the success of SAIs. This is particularly apparent in terms of the barriers that prevent people from undertaking initiatives that demand high levels of participation. At the individual level, education and income emerged as particularly significant in participatory governance studies, reflecting the wider sense in which citizenship-based activities are strongly circumscribed by the level of agency that different 
individuals are able to exert within particular contexts. For critics, this represents a failure to take structural constraints seriously, and recognise the ways in which marginal and vulnerable individuals and groups in particular struggle to transcend these.

\section{State-Society Relations: towards a new social contract?}

State-society relations have increasingly been recognised as critical to the politics of development, and SAIs constitute attempts to institutionalise more democratic and developmental forms of such relations, while also being closely shaped by their existing character. For Di John and Putzel (2009), social accountability is more likely to emerge when the political settlement, which is predominantly based on an agreement between elites on what the rules of the game are and how they should operate, becomes more inclusive of broader social groups. At this stage it becomes possible to discuss state-society relations in terms of a 'social contract', which refers both to the legitimacy of political rule, including the capacity of citizens to hold rulers to account, and also the pursuit of social justice as a fundamental principle of government (de Waal, 1996). ${ }^{2}$ The notion of a social contract thus offers a highly relevant framework for the politics of social accountability and social protection. Social accountability and social protection can each be understood as both flowing from, and helping to support, more democratic and socially just forms of social contract, as has been argued in relation to both participatory budgeting in Latin America (Goldfrank, 2007) and cash transfers in Brazil (Alston et al., 2013).

It is important to contextualize this notion of social contracts which derives from Western history and theories of state formation and change. Much literature on social accountability imagines a social world consisting of autonomous, well-informed and active citizens who are able to make demands of capable and responsive public officials (Hickey, 2011). In many 
developing contexts, state-society relations are heavily personalized or informal, and underpinned by a logic of patronage which is glaringly at odds with these Western theories of governance and change (Booth, 2012). Different forms of social contract will emerge in different contexts, depending in part on the balance and interaction between democratic and more clientelist forms of politics. For example, contracts can emerge within the context of semi-authoritarian regimes, usually on the basis of presidential patronage and/or a ruling party with an ideological commitment and/or strong incentives to offer certain public goods. In either context, elections can provide a window of opportunity for politicizing certain demands and beginning to forge new public agreements around them. This may mark the start (or part) of longer-term bargaining around this particular issue or public good, or could locate the provision of public goods insecurely in the field of asymmetrical reciprocity that defines patron-client politics in some contexts. For example, de Waal's (1996) analysis of social contracts around food security in Africa and India shows that the strongest such contracts have been derived from processes of popular mobilization at key moments of state formation, which then became institutionalized within constitutional commitments and protected by political institutions such as programmatic parties and parliaments more broadly. This also suggests that more research is required into the possibility that informal mechanisms may provide 'good enough' forms of accountability in certain contexts.

The broad notion of a 'social contract' can be broken down further by examining the agreements or settlements that exist around different sectors, or what others call the 'structural linkages' that bind states and citizens to each other (Skocpol, 1992). This is critical, as what is expected by citizens and what states are prepared to commit to delivering, varies according to the particular goods and services under discussion, their level of popular and political importance, and the history of state-society bargaining around them (Houtzager 
and Joshi, 2008). Assessing the possibilities for both locating SAIs within existing social contracts, and deepening them as a result, could therefore start from an analysis of how the rights of citizens to different resources and public goods have been differentially distributed over time and on what basis. Evidence that a social contract is operational in relation to a particular public good for at least some citizens may be derived in part from an examination of constitutional rights and provisions, as with the Right to Information campaign in India. However, it would be more strongly evidenced by the presence of an active process of popular pressure and state-society bargaining around this good (de Waal, 1996). Recent calls to 'go with the grain' of governance in developing countries (Booth, 2012) suggest that it might be wise for external actors to promote SAIs where such a degree of commitment already exists, rather than to seek out the creation of new social contracts around public goods that are not recognized within current bargains. It is important not to underestimate the contentious character of state-society relations however. A social contract approach may be able to shed considerable light onto the actual forms of power and politics that matter in securing accountability, but no easy routes have yet been devised to operationalising a social contract approach within development policy and practice (Hickey, 2011).

\section{IMPLICATIONS: SOCIAL ACCOUNTABILITY AND TRANSFORMATIVE SOCIAL PROTECTION}

Beyond emphasizing the extent to which social accountability interventions are profoundly shaped by the contexts within which they are located, this review has illuminated the particular forms of politics and power relations that matter most in shaping the success of such interventions. Several implications flow from this for thinking through how to conceptualise and promote social accountability moving forward, including within the realm 
of social protection. This final section draws out three main dimensions of this agenda at the level of analysis, design and also research. The first concerns the need to rethink social accountability in distinctly political, as opposed to technocratic, terms; the second involves revisiting the design of SAIs to render them more attuned to both the kind of evidence presented here and the contexts within which they are required; and the third relates to the need for a much stronger evidence base on how contextual factors shape social accountability interventions and outcomes.

\section{Politicising the theory and practice of social accountability: towards a social contract}

\section{approach}

Achieving improved levels of social accountability is a profoundly political challenge, not least because such initiatives often seek to challenge powerful vested interests in the status quo (McGee and Gaventa, 2011). Our findings strongly suggest that sustained and effective SAIs require a re-ordering of how politics operates, particularly in terms of the broader social contract between states and citizens. This conclusion resonates with other attempts to shift the theory and practice of social accountability away from a technocratic approach in a more political direction, including Fox (2007) and Joshi and Houtzager's (2012) distinction between 'watchdogs' and 'widgets.' In seeking to reframe social accountability in more political terms, Joshi and Houtzager draw on the 'polity approach', which Houtzager (2003) had earlier adapted from Skopcol's (1992) seminal work on the politics of welfare reform and social policy. Similar to our focus on social contracts here, the polity approach focuses on 'the ways in which state and societal actors are constituted, become politically significant, and interact across the public-private divide' (Houtzager, 2003: 13). A polity approach shows how politics is mutually constituted by state-society relations, and draws attention to four kinds of processes: (1) the processes of reform of state institutions; (2) the impacts of state 
institutions on collective actors interested in specific policy arenas; (3) the 'fit' between collective actors with specific goals and the points of access and leverage afforded by political institutions; and (4) path dependence of policies and social action' (Skocpol, 1992: 41). This involves reconceptualising social accountability as an 'ongoing political engagement by social actors with the state as part of a long-term pattern of interaction shaped both by historical forces and the current context' (Joshi and Houtzager, 2012: 146). Adjusting the lens in this way has important implications for policy and practice, some of which this paper turns to now, with specific reference to social protection.

\section{Design issues: a politically-attuned approach to SAIs}

Adopting a political rather than technical approach to social accountability means thinking less in terms of the 'widgets' that constitute the particular inputs of social accountability initiatives and more in terms of the 'watchdog' nature of social accountability actors. This is particularly appropriate given that 'the watchdog approach is more rooted in the organic politics of particular contexts' (Joshi and Houtzager, 2012: 158). In practical terms, this is now being recognized through an emphasis on developing the political capacities of CSOs and citizens to demand accountability, including through mobilisation and coalition-building (Menocal and Sharma, 2008, Agarwal and Van Wicklin, 2011: 7). However, the policy and operational focus clearly needs to go far beyond civil society. As Devarajan et al. (2011: 7) have identified: 'civil society's effectiveness will almost always depend on incentives and in particular the activation of sanctioning mechanisms, within the state. These may take the form of internal bureaucratic structures within implementing agencies, or formally independent institutions of accountability within the state, including the legislature, judiciary, auditing departments etc.' 
There are few grounds here for suggesting that SAIs are a panacea for improved levels of governance and development, and much to suggest that their success is closely determined by context and their interaction with other accountability mechanisms, most notably supply-led forms. As argued by Menocal and Sharma (2008: ix), support for 'voice-based approaches,' 'may prove problematic in terms of increasing voice without a parallel effort to build the effectiveness and capacity of state institutions to address growing demands and expectations'. In particular, our paper concurs with the more general sense in which 'much of what we call accountability reflects only the weaker category, answerability. While citizen-led or public initiatives often involve 'soft' peer or reputational pressure, they rarely involve strong enforceability' (McGee and Gaventa, 2011: 11).

The incentives to which state functionaries respond are as likely to require 'demand-' as well as 'supply-led' sources of power, particularly in contexts where democracy and the rule of law remain contested. This is where the disciplinary power required to ensure that accountability interventions achieve both enforcement and sanctions resides; and where more contextualised understandings of how such incentives operate are required. Several casestudies help make this point, from the role of presidential commitment around UPE in Uganda (Hubbard, 2007) through to the critical role played by mayors and other elected officials in ensuring bureaucratic buy-in to social accountability in Bangladesh (Mahmud, 2007), India (Chhotray, 2008) and Kenya (Nyamu-Musembi, 2006). Taken alongside our finding that increased levels of state capacity enhance the success rate of social accountability, this insight further emphasizes the need to re-balance the emphasis on demand-side approaches (World Bank, 2004) with a focus on also strengthening public authority. This resonates with the argument that achieving social accountability requires both the expertise and hierarchical discipline associated with top-down governance approaches as 
well as the legitimation and empowerment that can result from bottom-up approaches (Brett, 2003). Going further, Booth (2012) argues that social accountability is better conceived of as a 'collective action problem' rather than one of deficits in solely supply or demand.

Reconceived in this way, the promotion of greater accountability requires generating incentives for actors across the state-society divide to collaborate by 'creating space for local problem-solving and facilitating collective action' (Booth, 2012: 72). This reflects the earlier argument by Fox (2007) that institutionalized forms of accountability require coalitions between reformers in the state and participatory actors from civil society.

This has some important implications with regards the promotion of more effective and accountable forms of social protection in developing countries, including with regards the tendency for social protection to be promoted by external rather than domestic political actors. External actors often seek to deliver social protection through non-state mechanisms with accountability to be ensured via community-based involvement in the distribution and monitoring of goods. As noted above, however, the poorest and most vulnerable people who are the main target of social protection interventions are those worst-placed to generate the agency required to mobilise and hold public institutions to account. Popular agency requires able-bodiedness, an ability to articulate interests in accessible and affordable spaces of governance, and room for manoeuvre within social relationships, all things which are least available to the poorest (Cleaver, 2005). Furthermore, the modal form through which social protection mechanisms such as cash transfers are delivered may actually undermine the emergence of collective forms of agency, given both the nature of the good that is delivered and its targeting of individuals. Such private goods do not necessarily require the forms of collective public action which can be witnessed around demands for public goods such as education or the kinds of private goods that involve some degree of collective consumption as 
with housing and associated infrastructural requirements (Mitlin, 2006). That said, some important clues to squaring this apparent circle can be found in some instances of social protection where programme design has a stronger built-in focus on agency and rights. For example, the Vulnerable Groups Development Programme in Bangladesh requires that local people mobilise to receive the transfers in ways that promote empowerment of the poor rural women who constitute its main recipients (Hossain, 2007). Perhaps more promising still here, are public works programmes which have catalyzed high levels of collective bargaining, particularly when inscribed as a constitutional right as with the Maharastra Employment Guarantee Scheme (Moore and Jadhav, 2006) and now the Mahatma Gandhi National Rural Employment Guarantee Scheme (Joshi, 2010). Finally, a further implication may be that for social protection interventions to become more accountable and sustainable, there is a need to cast them as universal entitlements rather than means-tested benefits in order to align poor and non-poor groups around a shared sense of vulnerability (Nelson, 2003). This raises the possibility of non-poor groups bringing their often higher levels of agency to bear in terms of both maintaining social protection interventions and ensuring that they deliver.

Citizens and their organisations have not commonly been associated with promoting social protection in developing countries (Hickey, 2009). It therefore seems more likely that citizenled forms of accountability will emerge as citizens come to see the goods that are distributed to them through various social protection instruments as entitlements rather than as a form of patronage. It may well be that the growing and continued presence of social protection itself becomes the main driver of higher levels of accountability as recipients become used to receiving transfers and start to see them as entitlements for the long-run rather than temporally limited handouts associated more with a politics of patronage than rights. The formation of such 'policy constituencies' around social protection is evident at low levels in 
some countries already, as with the long-standing if minimalist Public Welfare Assistance Scheme in Zambia (Haarland, 2012). It was also apparent in earlier historical moments in sub-Saharan African countries where a social contract around food security appeared to be developing until a mixture of political conflict and disruptive forms of humanitarian aid intervened (de Waal 1996). This in turn has implications for the delivery of social protection and raises questions concerning the tendency to sidestep government delivery mechanisms for fear of leakage. Such moves have the potential to undermine the development of a social contract whereby social protection can become a 'structural linkage' binding states and citizens and a medium for wider forms of bargaining. From this social contract perspective, it makes sense to ensure that governments are closely involved in the distribution of social transfers and well-placed to reap the political benefits such as increased legitimacy. It is rare to secure win-wins in development policy and practice when it comes to politically and technically optimal solutions to service delivery. This paper suggests that 'politically optimal' solutions, which are 'good enough' from a technocratic governance perspective (Grindle, 2007) and which also serve political interests and goals in the short and longer-term may offer the best route forward.

\section{The challenge for research and evaluation}

A key finding of our investigation was that the evidence-base on what shapes SAI effectiveness is sorely lacking, particularly regarding the role of contextual factors, and most notably around how social accountability mechanisms are shaped by power and politics. This is particularly true of social accountability mechanisms within social protection interventions,

where the evidence base is especially weak. A key challenge moving forward is therefore to devise a stronger evidence base about SAIs from which to draw out a clearer understanding of the interactions between context and design. This offers further grounds for the now 
standard call for institutionalizing political analysis, or what some call higher levels of 'political intelligence', within donor agencies and programming procedures (Menocal and Sharma, 2008: v). More specifically, and in line with the move away from 'best-practice' to 'best-fit' type approaches, there is a need to find ways of ensuring that this involves a closer mapping of interventions onto the particular context, so that as far as possible social accountability interventions are designed and rolled out in line with '(a) supporting existing domestic initiatives and pressures for change, and (b) in ways that are consistent with the initial state of the polity' (Devarajan et al., 2011: 32). Given that politics differs significantly across countries, this 'suggests a procedural case for linking external support with diagnosis of the institutional functioning of a country, sector, region or wherever the focus of desired action is' (Devarajan et al., 2011: 32).

To achieve this, however, there is a need to radically alter the ways in which SAIs are currently designed, monitored and evaluated, including in the context of social protection interventions. Few of the dozens of social accountability studies that we reviewed paid any in-depth attention to the role of context and politics in shaping their success. This requires that the diagnostics performed to each stage of the process, from baseline studies, through monitoring to evaluation need to include a strong focus on the political and contextual factors that enable and constrain such interventions in particular places. As McGee and Gaventa (2011: 3) note, 'a learning approach to evaluation and final impact assessment would give power and politics a central place in monitoring and evaluation systems'. Part of the challenge here is to identify particular types of context, within which there are different possibilities for the effective implementation and success of different types of SAIs in social protection. There is some evidence of movement in this direction, as with the distinction that some make between two different types of context: one where there is a legal framework and 
political system that permits access to information, and civil society has capacity and the government is willing to engage; as against one where 'the legal framework and political will to allow civil society participation is weak or non-existent' (Agarwal and Van Wicklin 2011: 12). An alternative approach, suggested by recent work on 'political settlements', is to distinguish between polities in terms of how political power is organised on the one hand, and the level of institutional capacity and 'impersonality' of the state on the other (Levy, 2014). In terms of methodology, some promising alternatives are now being promoted to the highly popular quasi-experimental approach to programme evaluation in this field, which are better able to capture the complex interactions between social and political dynamics and interventions in specific contexts, including a 'theory-based' approach to impact evaluation (McGee and Gaventa, 2011: 26). ${ }^{3}$ This report has gone further to argue more specifically that the current weight of evidence on how context matters for SAIs can be best appreciated from a polity-based theory of change (Joshi and Houtzager, 2012) which views social accountability as part of an historical process through which state and non-state actors forge social contracts around particular public goods over time. Again, such a reframing offers the first step towards a fuller appreciation of the role of political context in shaping social accountability.

This paper has used a systematic review of current evidence on social accountability interventions to provide a theoretically- and empirically-informed basis on which to integrate such interventions within the field of social protection. Further work along the lines presented in this special edition is required to explore the extent to which SAIs face the same types of problems when promoted as part of social protection policies and programmes. However, some of the findings from this paper are particularly relevant and should provide some pointers as to how that work can move forward, both in theory and in practice. For example, 
our finding, along with many others, that the recent tendency to emphasize bottom-up forms of accountability as the pre-eminent strategy for achieving more responsive, empowering and effective forms of provision are misplaced. Achieving bottom-up forms of social accountability within social protection schemes targeted at poor and marginal people is likely to be particularly problematic, given that the capacity of citizens to engage in social accountability initiatives, and to hold public officials to account, is closely shaped and differentiated by power relations involving inequality and exclusion along multiple lines. Those most in need of social protection are thus the least able to exercise the agency required to demand accountability. There are also concerns that the nature of many social protection interventions will tend to further undermine popular agency via both individuating distribution mechanisms used such as cash transfers and the fact that social protection tends to offer private rather than public goods, and therefore do not necessarily require collective forms of action and bargaining to gain and maintain them. Gaining further insights into and seeking to unravel these conundrums will not be easy, although clues can be gained from some instances where social protection initiatives are designed in ways that both require and help to support demand-making by vulnerable groups. The politics of social protection and of social accountability both resonate strongly with the broader project of transforming statesociety relations in developing countries, and as such, there remains a powerful logic to pursuing their combined contribution to the deepening of social contracts in progressive directions. 


\footnotetext{
${ }^{1}$ Political commitment is a tricky concept to define, and for the sake of argument we define it narrowly here as 'the extent of committed support among key decision makers for a particular policy solution to a particular problem' (Post et al., 2010: 569). However, and as will become clear later in the paper, this policy-focused approach needs to be firmly located within the broader political context within which key decision-makers operate.

${ }^{2}$ See Hickey (2011) for a review of the conceptual basis of social contract thinking in international development, with particular reference to social protection.

${ }^{3}$ The same authors also call for 'an appreciation of complexity thinking and methods such as qualitative case studies, in-depth interviews, ethnographic studies or participatory methods' (McGee and Gaventa, 2011: 26).
}

\section{REFERENCES}

Agarwal, S. and Van Wicklin, W. A. (2011). How, When and Why to Use Demand-Side Governance Approaches in Projects. Social Development How-to-Notes. Washington DC: The World Bank.

Aiyar, Y. (2010). Invited Spaces, Invited Participation: Effects of Greater Participation on Accountability in Service Delivery. India Review 9(2): 204-229.

Alston, L.J., Melo, M.A., Mueller, B., and Pereira, C. (2013). Changing Social Contracts: Beliefs and Dissipative Inclusion in Brazil. Journal of Comparative Economics, 41(1): 4865.

Bebbington, A. J., S. Hickey, S. and Mitlin, D. C. (2008). Introduction: Can NGOs Make a Difference? The Challenge of Development Alternatives. in A.J. Bebbington, S. Hickey and D.C. Mitlin (eds) Can NGOs Make a Difference? The Challenge of Development Alternatives (pp.3-37). London: Zed Books.

Booth, D. (2012). Development as a Collective Action Problem: Addressing the Real Challenges of African governance. Synthesis Report of the Africa Power and Politics 
Programme. London: Overseas Development Institute. http://www.institutionsafrica.org/filestream/20121024-appp-synthesis-report-development-as-a-collective-actionproblem (accessed 11 March 2014).

Brautigam, D. (2004). The People's Budget? Politics, Participation and Pro-poor Policy. Development Policy Review 22(6): 653-668.

Brett, E. A. (2003). Participation and accountability in development management. The Journal of Development Studies, 40(2), 1-29.

Campbell, C., Cornish, F., Gibbs, A., and Scott, K. (2010). Heeding the Push from Below How Do Social Movements Persuade the Rich to Listen to the Poor? Journal of Health Psychology, 15(7), 962-971.

Chhotray, V. (2008). Political entrepreneurs or development agents: An NGO's tale of resistance and acquiescence in Madhya Pradesh, India. In A. J. Bebbington, S. Hickey, and D. C. Mitlin, (Eds.), Can NGOs make a difference? The challenge of development alternatives (pp. 261-278). London: Zed Books.

Cleaver, F. (2005). Rethinking Agency, Rights and Natural Resource Management. In S. Hickey and D. Mitlin (Eds.) Rights-Based Approaches to Development: Exploring the Potential and Pitfalls (pp.127-144). (Boulder: Kumarian Press).

Corbridge, S., Williams, G., Srivastava, M., and Veron, R. (2005). Seeing the state: Governance and Governmentality in India. Cambridge: Cambridge University press.

De Waal, A. (1996). Social Contract and Deterring Famine: First Thoughts. Disasters, 20(3), 194-205. 
Devarajan, S., Khemani, S., and Walton, M. (2011). Civil Society, Public Action and Accountability in Africa. The World Bank, Washington DC.

Devereux, S., McGregor, A. and Wheeler, R. S. (2011). Introduction: Social Protection for Social Justice. IDS Bulletin, 42(6), 1-9.

Di John, J. and Putzel, J. (2009). Political Settlements: Issues Paper. Governance and Social Development Resource Centre, University of Birmingham.

Evans, P. (2010). The Challenge of 21st Century Development: Building CapabilityEnhancing States. New York: United Nations Development Programme.

Fox, J. (2004). Empowerment and Institutional Change: Mapping 'Virtuous Circles' of StateSociety Interaction. In Alsop, R. (Ed.) (2004). Power, Rights and Poverty: Concepts and Connections (pp.68-92). Washington DC: World Bank/DFID.

Fox, J. (2007). Accountability Politics: Power and Voice in Rural Mexico. Oxford: Oxford University Press.

Fung, A., \& Wright, E. O. (2003). Deepening Democracy: Institutional Innovations in Empowered Participatory Governance. The Real Utopias Project IV. London and New York: Verso.

Goldfrank, B. (2007). Lessons from Latin America's Experience with Participatory Budgeting. In A. Shah, (ed.), Participatory Budgeting (pp. 91-126). Washington DC: The World Bank.

Gough, D., Thomas, J., \& Oliver, S. (2013). Learning from research: Systematic reviews for informing policy decisions. London: Institute of Education, University College London. 
Hickey, S. (2011). The politics of social protection: what do we get from a 'social contract' approach? Canadian Journal of Development Studies, 32(4): 425-438.

Hickey, S. (2013). Thinking About the Politics of Inclusive Development: Towards a Relational Approach. ESID Working Paper 1. Manchester: Effective States and Inclusive Development Research Centre.

Hickey, S., and Mohan, G. (2008). The politics of establishing pro-poor accountability: What can poverty reduction strategies achieve? Review of International Political Economy, 15(2), 234-258.

Hossain, N. (2010). Rude Accountability: Informal Pressures on Frontline Bureaucrats in Bangladesh. Development and Change, 41(5), 907-928.

Hossain, N. (2007). The politics of what works: the case of the Vulnerable Group Development Programme in Bangladesh. CPRC Working Paper 92. Manchester: Institute for Development Policy and Management.

Houtzager, P. \& Joshi, A. (2008). Introduction: Contours of a Research Project and Early Findings. IDS Bulletin, 38(6), 1-9.

Houtzager, P. (2003). Introduction: From Polycentrism to the Polity. In: Houtzager, P. \& Moore, M. (Eds.) Changing Paths: International Development and the New Politics of Inclusion (pp.1-31), Ann Arbor: University of Michigan Press.

Hubbard, P. (2007). Putting the Power of Transparency in Context: Information's Role in Reducing Corruption in Uganda's Education Sector. Washington: Center for Global Development. 
Joshi, A., and Houtzager, P. (2012). Widgets or Watchdogs? Public Management Review, $14(2), 145-162$.

Kabeer, N., Mahmud, S. \& Castro, J. G. I. (2010). NGOs' Strategies and the Challenge of Development and Democracy in Bangladesh. IDS Working Paper No.343. Brighton: Institute of Development Studies.

Khan, M. (2010). Political Settlements and the Governance of Growth-Enhancing Institutions. Mimeo. London: School of Oriental and African Studies.

King, S. (2015). Political capabilities for democratisation in Uganda: good governance or popular organisation building? Third World Quarterly, 36(4), 741-757.

Lavalle, A. G., Acharya, A., \& Houtzager, P. P. (2005). Beyond Comparative Anecdotalism: Lessons on civil society and participation from São Paulo, Brazil. World Development, 33(6), 951-964.

Leftwich, A. (2005). Politics in Command: Development Studies and the Rediscovery of Social Science. New Political Economy 10(4), 573-607.

Malena, C., and McNeil, M. (2010). Social Accountability in Africa: An introduction. In C. Malena and M. McNeil, (Eds.), Demanding good governance: lessons from social accountability initiatives in Africa, pp.1-28, Washington DC: The World Bank.

McGee, R., and Gaventa, J. (2011). Shifting Power? Assessing the Impact of Transparency and Accountability Initiatives. IDS Working Paper 383. Brighton: Institute of Development Studies. 
Menocal, A. R. and B. Sharma (2008). Joint Evaluation of Citizens' Voice and Accountability. Synthesis Report. London: Overseas Development Institute/DFID.

Mitlin, D. (2013). Politics, informality and clientelism - exploring a pro-poor urban politics. ESID Working Paper 34. Manchester: Effective States and Inclusive Development Research Centre.

Mitlin, D. (2006). The Role of Collective Action and Urban Social Movements in Reducing Chronic Urban Poverty. CPRC Working Paper No. 64. London and Manchester: Chronic Poverty Research Centre.

Moore, M. (2001). Empowerment at last? Journal of International Development, 13(3), 321329.

Moore, M., and V. Jadhav (2006). The Politics and Bureaucratics of Rural Public Works: Maharashtra's Employment Guarantee Scheme. Journal of Development Studies 42(8): $1271-1300$.

Nelson, J. (2003). Grounds for Alliance? Overlapping Interests of the Poor and Not So Poor. In P. Houtzager and M. Moore (Eds.) Changing Paths: International Development and the Politics of Inclusion (pp.119-138). Ann Arbor: University of Michigan Press.

North, D.C., J.J. Walliss and B.R. Weingast (2009). Violence and Social Orders: A Conceptual Framework for Interpreting Recorded Human History. Cambridge University Press.

O’Neill, T., Foresti, M. and A. Hudson, A. (2007). Evaluation of Citizens' Voice and Accountability: Review of the Literature and Donor Approaches. London: DFID. 
Post, L. A., Raile, A.N.W. and Raile, E.D. (2010). Defining Political Will. Politics \& Policy 38(4): 653-676.

Ramkuma, V. (2008). Our Money, Our Responsibility: A Citizens' Guide to Monitoring Government Expenditures. The International Budget Project. Washington DC: World Bank.

Robinson, M. (2006). Budget Analysis and Policy Advocacy: The Role of Nongovernmental Public Action. Paper for a panel on 'Negotiating Change and Striving for Justice: the Role of NGPA Actors', 6th CIVICUS World Assembly, Glasgow. (June 21-25).

Shankar, S. (2010). Can Social Audits Count? ACARC Working Paper 09. Canberra: Australia South Asia Research Centre. https://crawford.anu.edu.au/acde/ asarc/pdf/papers/2010/WP2010_09.pdf (accessed 28 February 2014).

Skocpol, T. (1992). Protecting Soldiers and Mothers Cambridge, MA: The Belknap Press.

Sundet, G. (2008). Following the Money: Do Public Expenditure Tracking Surveys Matter? U4 Anti- Corruption Resource Centre Issue 8. Bergen: U4-Chr. Michelsen Institute.

Unsworth, S. and M. Moore (2010). An Upside Down View of Governance. Brighton: Centre for the Future State - Institute of Development Studies.

vom Hau, M. (2012). State Capacity and Inclusive Development: New Challenges and Directions. ESID Working Paper 2. Manchester: Effective States and Inclusive Development Research Centre.

World Bank (2001). World Development Report 2000/1: Poverty. World Development Reports. Washington DC: The World Bank. 
World Bank (2004). World Development Report 2004: Making services work for poor people. World Development Reports. Washington DC: The World Bank.

World Bank (2014). World Development Report 2014: Risk and Opportunity. World Development Reports. Washington DC: The World Bank. 